\title{
Characterization of some nonmetallic resources in Bolivia: an overview of their potentiality and their application in specialized formulations
}

\author{
Ariana Zeballos $^{1,2} \cdot$ Pär Weihed ${ }^{1} \cdot$ Mario Blanco $^{2} \cdot$ Vladimir Machaca $^{2}$
}

Received: 21 May 2016/Accepted: 23 October 2017/Published online: 10 November 2017

(c) The Author(s) 2017. This article is an open access publication

\begin{abstract}
Bolivia has several nonmetallic occurrences widespread in the country. Unfortunately, they are poorly studied and slightly characterized. In the present work, several nonmetallic occurrences located in La Paz, Oruro, Potosí and Santa Cruz were studied. The results of the chemical and mineralogical characterization of the materials will be presented, in order to approach their applicability in specialized industrial formulations. A preliminary test of the final products besides an overview of their potentiality will be exposed and a current view of the commercialization as well.
\end{abstract}

Keywords Bolivian raw materials $\cdot$ Zeolites $\cdot$ Diatomite Mullite $\cdot$ Clays $\cdot$ Kaolins

\section{Introduction}

It is becoming increasingly difficult to ignore the importance of the industrial minerals in the present life. The industrial minerals and rocks cover a wide range of uses, from everyday products such as ceramics, soaps and medicine to high technology such as molecular sieves to rocket components.

However, the literature shows nothing or little work about the potential of Bolivia as a nonmetallic raw material miner as well as a producer. Most studies on the

Ariana Zeballos

Ariana.Zeballos@1tu.se

1 Division of Geoscience and Environmental Engineering, Luleå University of Technology, 97187 Luleå, Sweden

2 Instituto de Geología y del Medio Ambiente, Universidad Mayor de San Andrés, La Paz, Bolivia nonmetallic potentiality have been only carried out in a small number of occurrences, and the literature commonly refers those nonmetallic minerals as gangue minerals or alteration products from hydrothermal processes that are commonly associated with metallic mineralizations. The construction industry is one of the largest industries in Bolivia. The red brick producers at Llojeta in $\mathrm{La} \mathrm{Paz}$ (Fig. 1) send the majority of the production to the border towns near Chile and Perú. The kaolin materials from La Bella in Santa Cruz are well known for the white tile manufacturing which captures the internal consumption. For several years, the bentonites from Coro Coro and Río Mulatos were mined to produce cat litters and drilling muds, respectively. Despite of, a little literature exists about these prosper resources, the quality of the raw materials are unknown.

This paper will examine the potentiality of Bolivia in nonmetallic minerals as well as its capability to transform nonmetallic raw materials in specialized products such as building materials and zeolites. This paper first gives results about the chemical and mineralogical characterization of four important raw materials such as diatomites, clays, zeolites and refractory minerals and finally will give and overview of their potential application in the daily life.

In the last 10 years, the nonmetallic resources and their consumption have been growing up (Fig. 2). In countries such as Bolivia that is known as a potential mineral producer, the mineral resource exploration is focused in metallic ores such as tin, silver, lead, zinc or gold, leaving aside the nonmetallic minerals such as clays, feldspars (Fig. 3) and the industrial minerals, remain unstudied and poorly understood. 

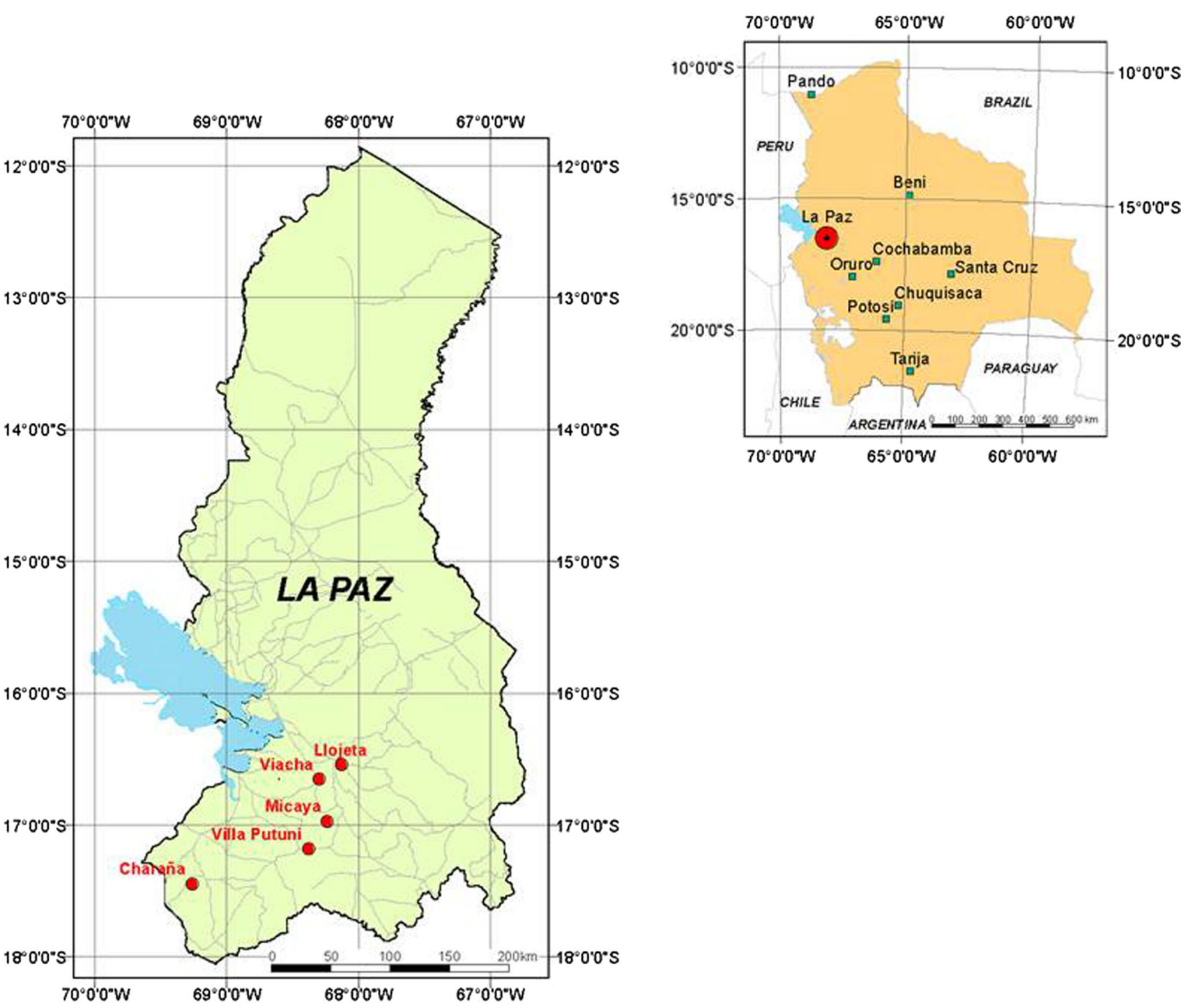

Fig. 1 Location map of the studied deposits in La Paz, Bolivia

Fig. 2 World Market from nonmetallic mineral mining (2004-2014), data source from Parker (2008)

\section{World Market for Non-Metallic Mineral Mining:2004-2014 US \$ mln}

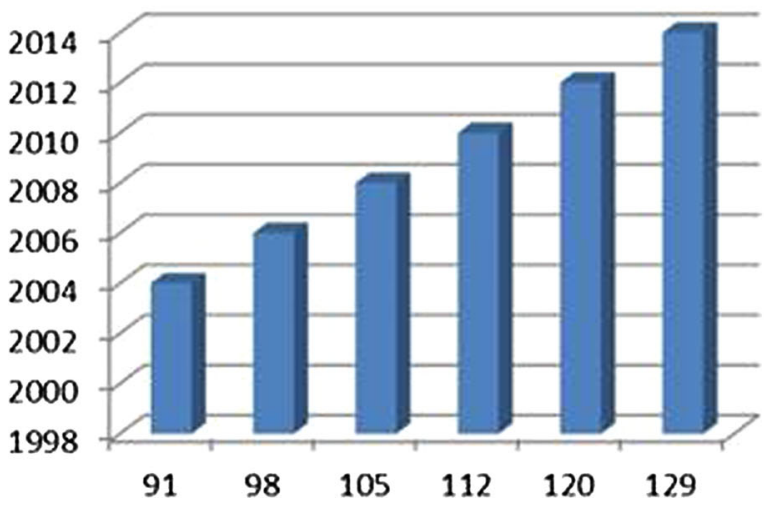

World Market for NonMetallic Mineral Mining:2004-2014 US \$ $\mathrm{min}$ 
Fig. 3 Bolivian market for nonmetallic mineral mining

\section{Bolivian Market for Non-Metallic Mineral Mining:2004-2014 US \$ mln}

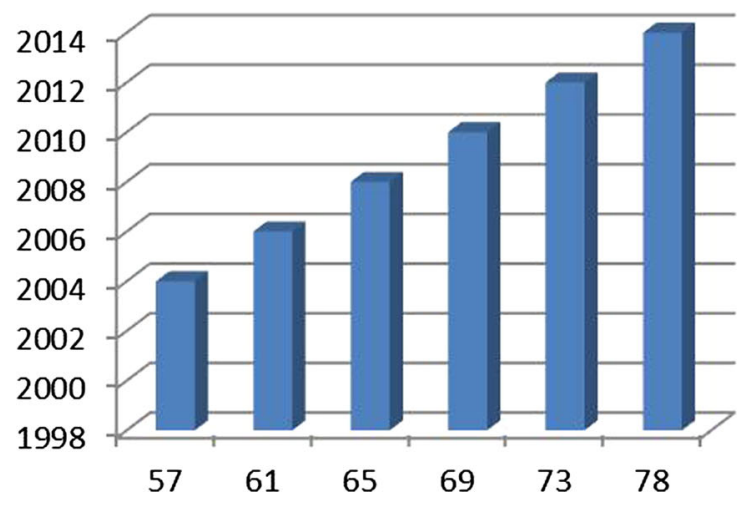

Bolivian Market for NonMetallic Mineral Mining:2004-2014 US \$ $\mathrm{mln}$

\section{Materials and methods}

The availability of raw materials was obtained through geological mapping and sampling. In the Micaya (Fig. 1), Charaña (Fig. 1) and Murmutani deposits, geological mapping was performed in a 1:20,000 scales (Zeballos et al. 2016; Acarapi 2013). In Rio Mulatos, Corque and Santa Cruz, chemical and mineralogical analyses were performed. The chemical analyses were carried out in the ALS laboratory in Sweden, according to the EPA method (modified) 200.8 (ICP-SFMS), where $0.1 \mathrm{~g}$ sample was fused with $0.4 \mathrm{~g} \mathrm{LiBO}_{2}$ and dissolved in $\mathrm{HNO}_{3}$. LOI (loss on ignition) is done at $1000{ }^{\circ} \mathrm{C}$. The mineralogical characterization was done using a PANalytical Empyrean $\mathrm{X}$-ray Diffractometer equipped with $\mathrm{Cu}$ LFF HR X-ray tube, a graphite monochromator and a PIXcel3D detector. The diffractometer was operated at $30 \mathrm{~mA}$ and $40 \mathrm{kV}$. The scanning region of the diffraction angle $2 \theta$ was from $5^{\circ}$ to $50^{\circ}$ with a 0.026 step size and time per step of $250 \mathrm{~s}$ in the LTU laboratories in Luleå, Sweden, and a X'Pert3 PANalytical instrument using $\mathrm{Cu}$ Ka radiation and time step increments of 0.010_/s, at the IGEMA laboratory, in La Paz. Mineral identification and quantification were determined with the help of the X'Pert High Score Plus software according to the X-ray spectral peak (Brown and Brindley 1980; Moore and Reynolds 1997).

\section{Results and discussion}

\section{Synthetic and natural zeolites}

Zeolites were first identified in 1756 as a group of minerals by a Swedish mineralogist, Baron A.F. Cronstedt (Eyde and Holmes 2006). Zeolites are hydrated aluminosilicates with a three-dimensional $\mathrm{SiO}_{4}$ tetrahedral framework-type structures with molecular cavities and molecular channels
(Chang 2002). Zeolites minerals can contain loosely bounded alkali and alkaline earths metals that could be easily exchanged for other cations or molecular water (Eyde and Holmes 2006). More than 48 natural zeolites have been well characterized and more than 100 were produced synthetically (Chang 2002; Eyde and Holmes 2006).

Recent studies with local raw materials (Garcia et al. 2015) such as those located in Charaña (Fig. 1) are pointed out, as well as diatomites and montmorillonites from Río Mulatos located in Potosí to be used as raw materials besides kaolin to produce synthetic zeolites to be used in catalytic cracking and detergent industry. Garcia et al. (2015) performed a synthetization of a submicron FAUtype zeolite using an acid-treated diatomite from a diatomaceous earth deposit, as well as zeolite "A" using a natural clay, and montmorillonite from the smectite family (García et al. unpublished results); both are raw materials from two deposits located in Potosí, Bolivia. On the other hand, chemical analysis (Table 1) and mineralogical analysis (Table 2) performed on the samples reveal similar applications of those materials (diatomaceous earth) at Charaña and those minerals (montmorillonitic clay) from Villa Putuni (Fig. 4) located in La Paz. The studied similar geological conditions of origin and preliminary tests (García personal communication.) are also similar. The geological features, chemical analyses and preliminary applications of these nonmetallic minerals will be discussed below.

Diatomaceous earth resources in La Paz

- At the western side of the Bolivian Altiplano in the Pacajes Province is located the Charaña town, at 250 km from La Paz city (Fig. 1) above 4069 m.a.s.l. In the area, diatomaceous earth's resources are present. Diatomites or diatomaceous earths are siliceous 
Table 1 Chemical analyses of the studied materials

Table 2 Mineralogical analyses of the studied materials, using XRD method

Fig. 4 Montmorillonite layers from Putuni, La Paz

\begin{tabular}{lcccc}
\hline Kaolinite Micaya & Kaolinite La Bella & Kaolinite Benton & Illite Llojeta & Illite Viacha \\
\hline $70.5-74.2$ & 49.3 & $49.8-49.9$ & $48.8-55.8$ & $51.6-53.7$ \\
$17-17.9$ & 34.5 & $29.3-29.1$ & $22.4-18.1$ & $18.8-22.7$ \\
$0.13-0.14$ & $<0.08$ & $<0.08$ & $0.16-0.17$ & $0.45-1.01$ \\
$1.27-1.32$ & $<0.1$ & $0.13-0.12$ & $5.0-5.34$ & $7.06-8.04$ \\
$3.82-4.01$ & 1.86 & $3.89-5-16$ & $3.18-3.72$ & $2.92-3.98$ \\
$0.67-0.70$ & $<0.02$ & 0.019 & $1.32-1.60$ & $1.60-1.62$ \\
$0.02-0.03$ & 0.0137 & 0.01 & $0.01-0.02$ & $0.12-0.19$ \\
$0.09-0.11$ & 0.521 & $0.10-0.19$ & $0.81-0.84$ & $0.75-1.10$ \\
0.07 & $<0.009$ & 0.0099 & $0.06-0.08$ & $0.12-0.13$ \\
$0.94-0.98$ & 0.0027 & 0.0059 & $0.72-0.74$ & $0.81-0.93$ \\
\hline
\end{tabular}

\begin{tabular}{ll}
\hline Samples & Mineralogical phases \\
\hline Diatomite "Charaña" & Halite; phlogopite; montmorillonite \\
Zeolite "Corque" & Mordenite; montmorillonite \\
Diatomite "Murmutani" & Halite; tridymite; muscovite \\
Montmorillonite "Villa Putuni" & Montmorillonite; mordenite \\
Montmorillonite " Río Mulatos" & Montmorillonite; anorthite \\
Kaolinite "Micaya" & Quartz; kaolinite; muscovite; orthoclase \\
Kaolinite "La Bella" & Kaolinite; sanidine \\
Kaolinite "Benton" & Kaolinite; sanidine; phlogopite \\
Illite "Llojeta" & Quartz; muscovite; montmorillonite; sanidine; clinochlore \\
Illite "Viacha" & Quartz; clinochlore; muscovite \\
\hline
\end{tabular}

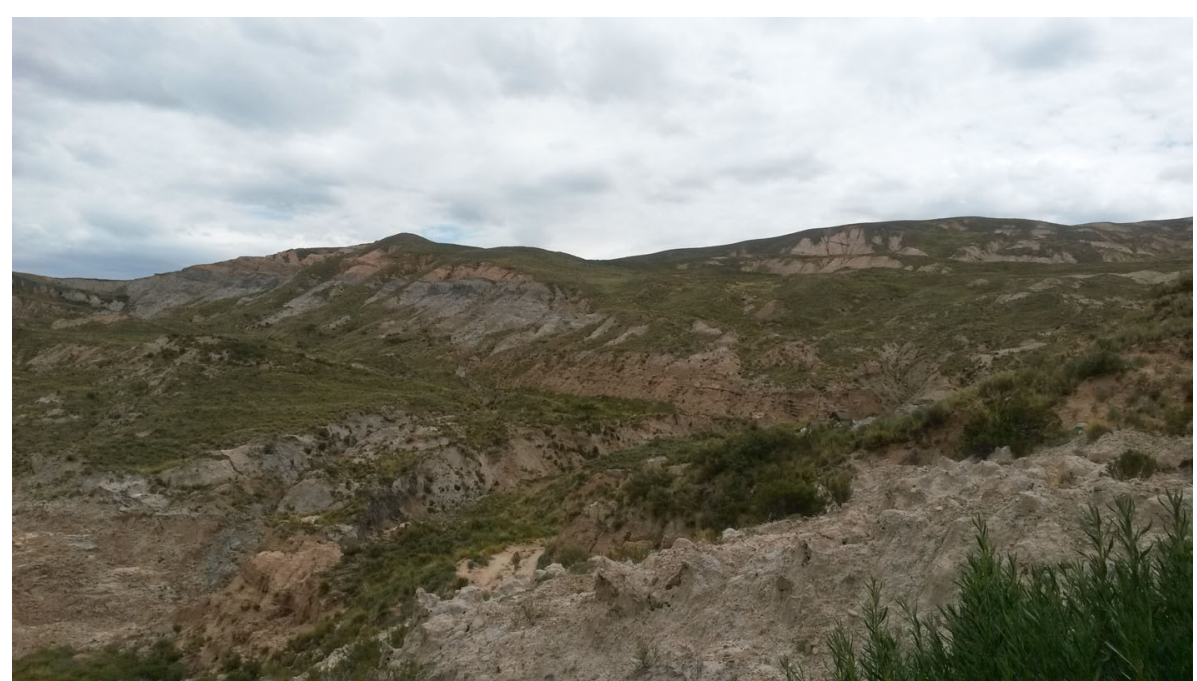

sedimentary rocks consisting mainly of fossilized remains of microscopic aquatic plants (diatoms); they are highly porous, and their major industrial uses are as a filter aid and as a functional filler in paint, paper, rubber and plastics (Chang 2002; Eyde and Holmes 2006).

The diatomites from the Bolivian Altiplano were first studied by Frenguelli (1939), and later on Servant-Vildary
(1978) pointed out 34 species of diatom algae in some lacustrine sediments of the Altiplano. In the Charaña area were recognized three of these species for the lacustrine sediments: Nitzschia amphibia Grun, Navicula salinarum Grun and Navicula plicata Donkin (Servant-Vildary 1978). Mastoglia atacamae Hustedt was determined later on as a new species, a species from the M. elliptica group identified in the sediments of the Charaña Fm. at Charaña 
(Servant-Vildary and Blanco 1984). Servant-Vildary and Blanco (1984) have also identified Rhopalodia gibberula and Nitzschia punctate Grun, which have been also identified in the new collected samples (Fig. 5a, b).

In 1975, a research board conformed by the US Geological Survey and the Bolivian Geological Survey (1992) reported several deposits of diatomaceous earth. All the material located in lacustrine sediments associated with evaporitic deposits southward the Altiplano, which consist of $10^{6}$ tons of diatomaceous earth in $65-91 \%$ of purity; the above-mentioned material is located also in the Tauca Fm as well as in the Charaña Fm. at Charaña (U.S. Geological Survey and the Bolivian Geological Survey 1992). The Charaña Formation lies discontinuously above the Perez ignimbrite dated at 2.2-3 Ma. The Charaña Formation was

\section{(a)}

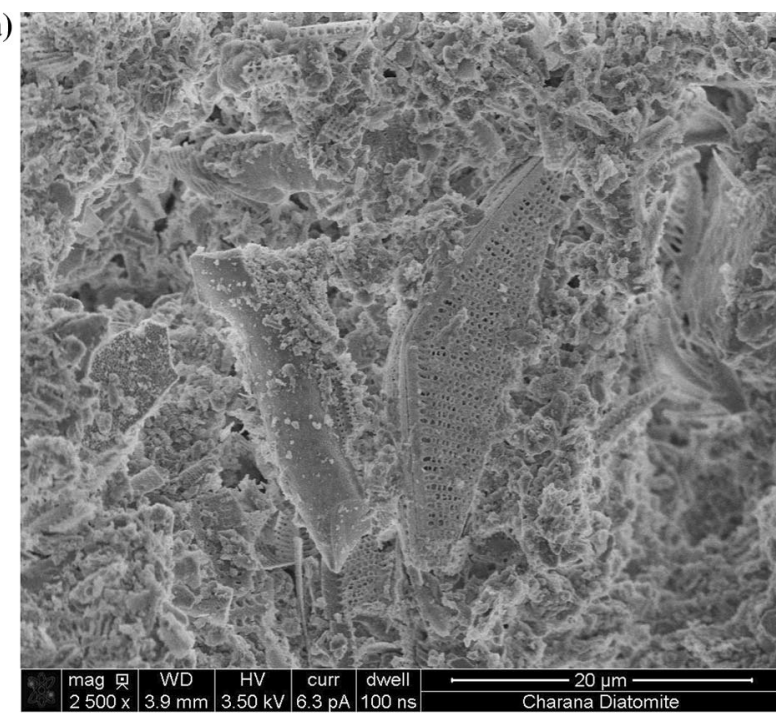

(b)

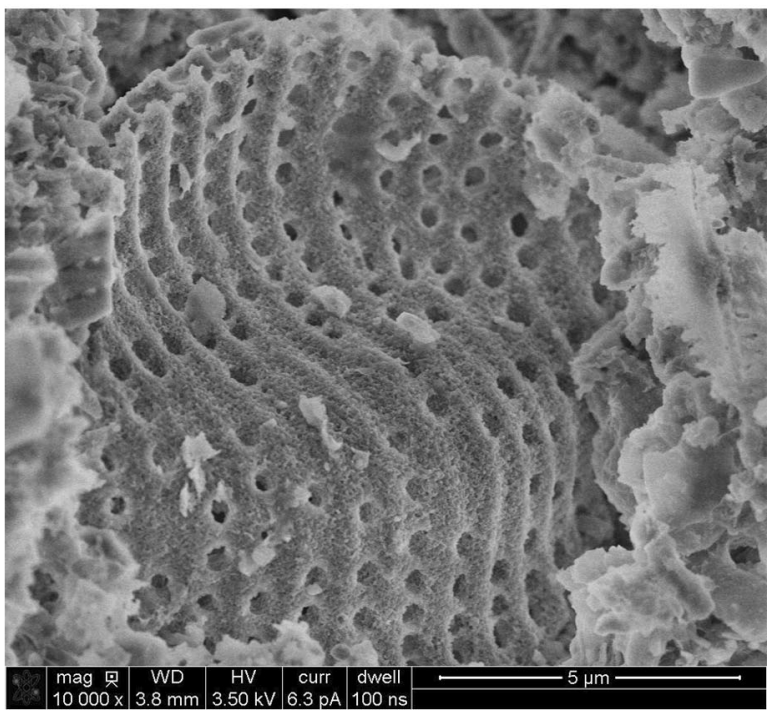

Fig. 5 SEM backscattered images from the diatomaceous earth of Charaña: a Rhopalodia gibberula and b Nitzschia punctate Grun (Servant-Vildary and Blanco 1984) dated in feldspars and biotites by the $\mathrm{K}-\mathrm{Ar}$ method (Everden et al. 1966). The volcano-sedimentary sequence of the Charaña Fm is composed of diatomaceous layers of about 40-60-m-thick of plio-pleistocene age (ServantVildary and Blanco 1984). Chemical analysis of diatomaceous earth samples from Charaña (Table 1) shows a high content of silica, that corroborates the mineralogical analysis along with halite, phlogopite and montmorillonite as impurities in the mixture (Table 2).

Blanco et al. (2003) pointed out a new application of the diatomaceous earth located in Charaña. The use of the diatomaceous material along with $\mathrm{CaCO}_{3}$ (p.a.) in a synthetization process of wollastonite $\left(\mathrm{CaSiO}_{3}\right)$ a calcium silicate with acicular crystal habit. The wollastonite is used in ceramic formulations to promote dimensional uniformity, low shrinkage and fast firing, as well as in paints and plastics as filler (Chang 2002). The synthetization has been achieved by calcination of the diatomaceous earth and $\mathrm{CaCO}_{3}$ mixture in relation $2: 1$, in a muffled oxidizing environment by natural air flow at $1100{ }^{\circ} \mathrm{C}$ for $48 \mathrm{~h}$ (Blanco et al. 2003).

Acarapi (2013) has studied the Charaña material for use in water purification in which work, a study on its potential as a mineral resource has been carried out concluding an approximate reserve of $16,414,200 \mathrm{~m}^{3}$, which is present as a whitish layer $10 \mathrm{~m}$ thick over $1.64 \mathrm{~km}^{2}$ of lacustrine sediments from the Charaña Fm.

Associated with the lacustrine sedimentary units and tuffs in the Charaña basin, in amygdales of the basaltic quaternary units, some zeolite minerals have been also identified (Soria-Escalante, unpublished results, 1990). The Charaña basin is an enclosed basin in the Altiplano and has been occupied by alkaline lakes and salars during the Holocene, which were formed in the presence of volcanic activity; therefore, according to Ludington et al. (1992) in the Charaña basin the zeolites were formed under the same conditions as those formed southward the Altiplano.

Literature about natural zeolite occurrences in Bolivia is poor, and chemical or mineralogical description of these occurrences is scarce. Arduz and Mobarec (1994) and Mobarec et al. (1996) in their study about the geology of the Corque area located $68 \mathrm{~km}$ from Oruro, in the ToledoHuachacalla rout, have described a whitish layer from the upper level of the Huayllamarca Formation which conformed with gray sandstones; the whitish layer has been recognized as a zeolite occurrence derived from hydrothermal alteration of a dacitic sill $200 \mathrm{~m}$ long and $50 \mathrm{~cm}$ wide; 1000 tons of material was estimated (Rivas 2002). In this work, chemical (Table 1) and mineralogical analyses (Table 2) were performed on the collected samples and a zeolite type named as mordenite was identified (Fig. 6).

The layer is a zeolitic sill intruding sedimentary units associated with hydrothermal alteration of igneous rocks. 


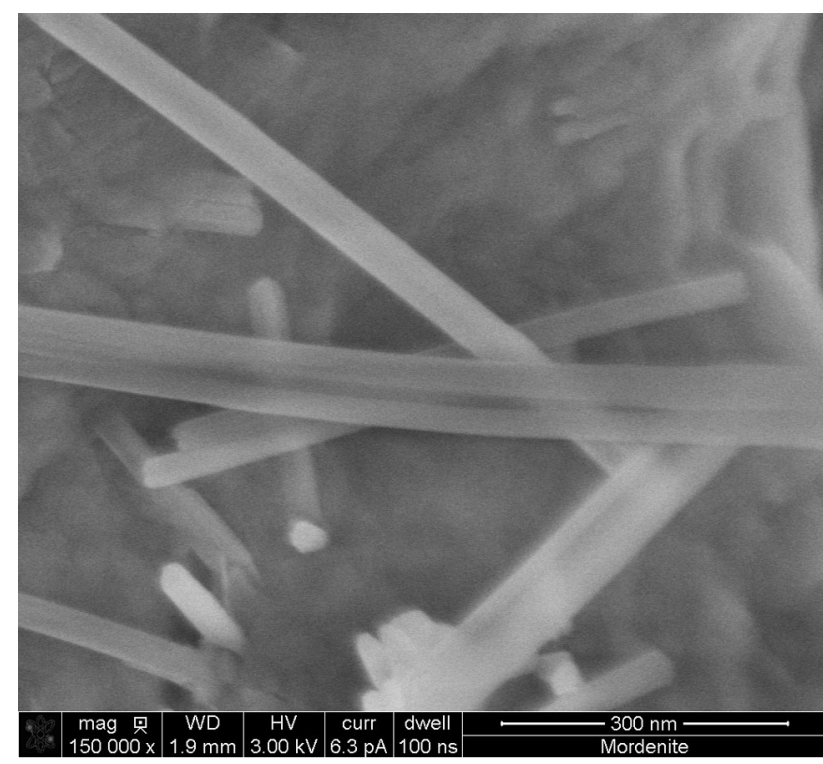

Fig. 6 Acicular crystals of mordenite from Corque

The mineralogical analysis (Table 2) confirms a mordenite-type zeolite in the rock with montmorillonite as a minor component; the chemical analysis shows $59.2 \mathrm{wt} \% \mathrm{SiO}_{2}$, 15.2 wt. $\% \mathrm{Al}_{2} \mathrm{O}_{3}$ as major components and $2.83 \mathrm{wt} . \% \mathrm{CaO}$ and 4.34 wt.\% $\mathrm{MgO}$ as minor components. The Si/Al relationship is $3: 1$, characteristic from a mordenite-type zeolite (Fig. 6).

\section{Diatomaceous earth resources in Bolivia}

Shenk (1991) has pointed out basinal characteristics for diatoms accumulations: (1) extensive, shallow basins for photosynthesis; (2) an abundant supply of soluble silica and nutrients; (3) an absence of toxic or growth-inhibiting constituents; (4) sustained high rates of diatom reproduction; (5) minimal clastic, chemical and organic contamination and (6) a low-energy environment for the preservation of the delicate diatom structure. Into the Altiplano, all these parameters were present during the past time. From the beginning of the quaternary age, lacustrine extensions have been developed due to the high volume of water as result of melting glaciers (Servant and Fontes 1978) that originated several lakes in the central basin such as Mataro lake, Cabana lake, Ballivian lake, Minchin lake, Tauca lake and nowadays the Titicaca lake (Lavenu 1991); therefore, occurrences of diatomites are common. For many years, several authors have identified diatoms occurrences in the Altiplano (Servant-Vildary 1978; Ballivian and Risacher 1981; Servant-Vildary and Blanco 1984; Ludington et al. 1992), and in the "Laguna Colorada" in South Lipez Province of Potosí, these deposits have been described by Orris et al. (1992) along with borates and sulfates in the basin.
Located in Potosí near Llica town a diatomaceous earth deposit has been mentioned by Rivas (2002) and first studied by Blanco and Zeballos (unpublished results, 2010) and Acarapi (2013); in his studies about diatomaceous resources for water purifying application, the material was described and the area was geologically characterized. The material is described as light in color and highly porous, geologically characterized by strato-volcanic series, Miocene in age, folded and faulted overlaid by tuff sequences (Cortez and Lima 2002). Rivas (2002) calculated 150,000 tonnes of the material with $80 \%$ of purity distributed in layers of $1.30 \mathrm{~m}$ of thickness. The mineralogical analyses (Table 2) performed in this work show amorphous material as a major component followed by tridymite, halite and muscovite. Scanning electron microscopy analyses (Fig. 7a, b) show diatoms as the major component of the

(a)

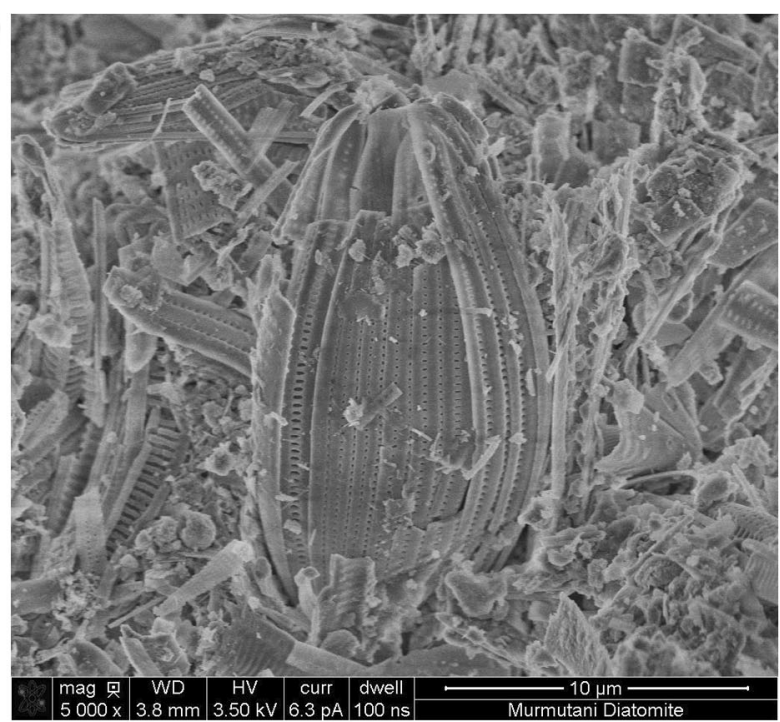

(b)

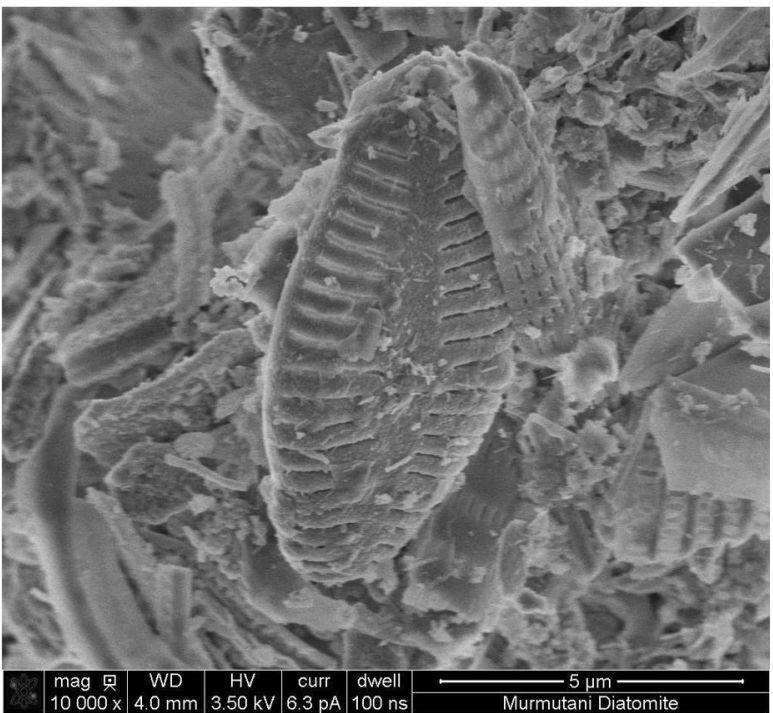

Fig. 7 SEM backscattered images from the diatomaceous earth of Murmutani, Llica 
rock, corroborating this way the higher silica oxide content in the chemical analyses (Table 1).

A lacustrine sedimentary basin is located $50-60 \mathrm{~km}$ south of Tarija and constitutes the Padcaya basin in which diatomite horizons are present within three sectors: Padcaya, Huacanqui-Potrero and Phayo (Troëng et al. 1993). The horizons vary between 0.1 and $1.1 \mathrm{~m}$ in the Padcaya sector with a relatively low silica content compared with the fairly high alumina and iron, the $0.5-\mathrm{m}$ and 3-m-thick outcrop in the Huacanqui-Potrero area (Troëng et al. 1993) and one horizon of 2.0-3.6 m thickness at the Phayo sector (Arduz et al. 1991).

\section{Montmorillonitic clay resources in La Paz}

- Villa Putuni (Fig. 1) is located in the Pacajes Province $102 \mathrm{~km}$ away from La Paz city. Located close to the Coro Coro mine, which hosts the most important copper mineralizations of Bolivia. The area hosts important resources of bentonites which are already in exploitation for the pet litter industry; although the resources belong to the community, a few families are benefited by them.

The montmorillonites are members of the silicate family with dioctahedral structure and could be highly expanded minerals if wet (Chang 2002).

The clay mineralization in the area is distributed in three thick layers from the Kollu Kollu Formation and has been identified as montmorillonite (Table 2; Fig. 4), green, red and gray in color due to some elemental characteristic of each layer. Chemical and mineralogical analyses show purity in the studied materials, allowing it to be used in zeolite synthetization (Panoso 2015). Tables 1 and 2 show mineralogical and chemical results of the collected samples. Panoso (2015) has calculated an exploitable material of $10,949,450 \mathrm{~m}^{3}$, especially to be used in zeolitic synthetization, due to its purity.

\section{Montmorillonitic clay resources in Bolivia}

In the geological descriptions of Bolivia, two montmorillonitic deposits were referred as important in the literature, "La Encontrada" and "Rio Mulatos." La Encontrada deposit at the Coro Coro district area in La Paz has been identified as bentonitic occurrences associated with copper. The Rio Mulatos deposit is located in Potosi and is represented by bentonitic materials associated with polymetallic vein ores.

Located in the northern part of the Altiplano is the Coro Coro mine. Coro Coro is the main copper mine of Bolivia, where several studies and mining works have been carried out in the area. The studies were focused on the geological knowledge and the chemical analyses in the copper content in the sedimentary units. Near the Coro Coro town is located the Coro Coro mining district, which is composed of sediments from the Ballivian (formerly Vetas Fm.) and Caquiaviri (formerly Ramos Fm) formations. The literature refers to copper replacement clays as a geological model of the copper assemblage (Entwistle and Gouin 1955; Cox et al. 1992) although the clay was not identified and properly characterized, being the metallic mineralogy more important than the nonmetallic minerals; in this work, several samples were collected in the Coro Coro area and chemical analyses (Table 1) and mineralogical test (Table 2) were performed on the clay minerals. In the Chacarilla district as well as in the Coro Coro district, bentonized sediments were studied (Guerra and Ascarrunz 1964a, b). In "La Encontrada mine," tertiary bentonized tuff bed on the west flank of a northwest trending anticline has been identified and analyzed; the altered bed is composed of 85-99\% montmorillonite as the main phase along with quartz, biotite and iron oxides (Guerra and Ascarrunz 1964a, b).

In both areas, the montmorillonitic clay appears to be the result of the hydrothermal alteration which originated the copper mineralization. The montmorillonite clay is probably that material described by Cox et al. (1992) in some other copper mines such as in the Pisaqueri mine.

Río Mulatos is another polymetallic mining district located in Potosí; veins of $\mathrm{Au}-\mathrm{Ag}-\mathrm{Sb}$ represent the disseminated mineralization; also uranium occurrences and alluvial gold are present along with important nonmetallic mineralization determined as montmorillonites from altered massive ignimbrites (Almendras et al. 2002). Close to the Río Mulatos mining district, in the Phasa Kollu Hill and the Maria Eugenia Hill, bentonite-bearing rocks with $70-90 \%$ of purity have been discovered and estimated reserves of 200,000 tons and 900,000 tons, respectively, calculated (Rivas 2002). Encinas et al. (2007) in their study about cadmium absorption properties of clays pointed out the use of clays and natural zeolites as metal absorbents of surficial waters around mining districts. They performed the studies using a montmorillonitic raw material from Río Mulatos and a natural zeolite from Corque, aforementioned; however, neither the mineralogical nor the chemical analyses of both raw materials were presented in the results. In this work, several analyses were carried out in both areas. In the Río Mulatos area, the mineralogical analyses (Table 2) show montmorillonite as the main component of the mixture and anorthite as impurity, and the chemical analyses (Table 1) show 53.0-57.1 wt.\% $\mathrm{SiO}_{2}$ and 19.7-21.5 wt.\% $\mathrm{Al}_{2} \mathrm{O}_{3}$ as major components and 2.49-2.95 wt.\% $\mathrm{CaO}$ and 3.71-3.85 MgO as minor components. The mineralogical and chemical analyses of the zeolite have been presented above. 


\section{Clays for building materials}

The term applied to building materials covers any material to be used with construction purposes such as red bricks, cement, aggregates, tiles, etc. In this section, three sedimentary deposits in La Paz will be discussed (Fig. 1), a kaolinitic material from a residual deposit (Zeballos et al. 2016) and two well-known illitic-rich clay deposits currently in exploitation as raw materials for the red brick industry.

The economic evaluation of a clay deposit is related not only to the nature of the materials, but also to the exploitation, the cost of transportation and the processes to achieve the finished product from the raw material as well. All these parameters will play an important role in the final price of the product. The manufacturing processes are almost the same in all ceramic formulations; the process as many authors pointed out (Carty and Senapati 1998; Moharem and Saleh 2007; Sanfeliu and Jordán 2009) starts with shaping the raw material using specialized equipment according to the finished product obtained. Drying is the second step necessary to avoid fractures during the firing stage: firing it to a certain temperature according to the desired finished product and the mineralogical composition of the raw materials used in the product. In the specific case of tile manufacture, the final step is the glazing. Sanfeliu and Jordán (2009) pointed out the importance of the geological work in the deposits; besides, the analytical methods to determine the quality of the clay to obtain the best quality finished product have also been indicated.

According to the National Statistical Institute from Bolivia (2013), the exportation of ceramic product for the construction area has grown over 300-fold in the past 10 years, while the ceramic importation has grown over 500 -fold in the past 10 years.

In this review, geological features, chemical analyses and an overview of final applications of the three deposits and end uses in ceramic will be discussed below.

\section{Kaolinitic clay resources from Micaya}

- Micaya town is located $75 \mathrm{~km}$ away from La Paz city (Fig. 1) and has a population of 300 inhabitants who live mainly from the agricultural work. In Micaya, a kaolinitic deposit has been found (Blanco et al. 2003) and it has been described firstly by Zeballos et al. (2009), described as whitish material, residual in origin, hosted between the layers of the Vila Vila Formation (Zeballos et al. 2016, Fig. 8).

At the bottom of the Devonian sedimentary sequence is located the Vila Vila Formation, composed of quartzitic sandstones and siltstones, overlaid by the Belen Fm.

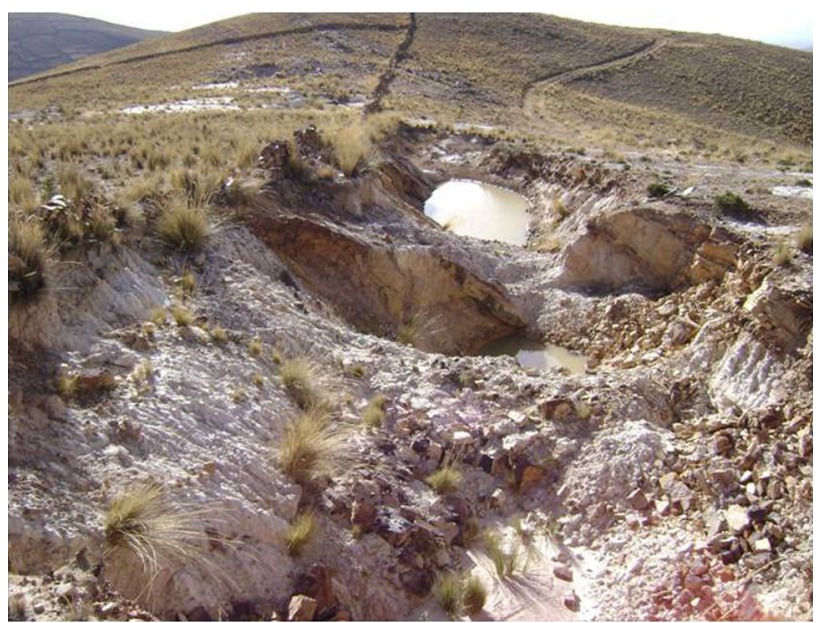

Fig. 8 Kaolinitic deposit from Micaya, La Paz

(siltstones), Sica Sica Fm. (sandstones) and Collpacucho Fm. (sandstones), discordant to the Devonian sequence is the Neogene Umala Fm. and Remedios Formation, which is composed of tuffs (Zeballos et al. 2009). According to Soria (1980), the Remedios Formation is a result from the Cenozoic magmatism in the Altiplano. Preliminary studies in the material (Fig. 8) (Blanco et al. 2003; Zeballos et al. 2009) show quartz and kaolinite as the main components in the mixture. Plasticity test (Zeballos et al. 2014, 2016) demonstrated their suitability in the ceramic industry; the material has been worked out for the local population to handmade kitchenware (pots and dishes). Geological mapping and several analyses, such as chemical (Table 1), mineralogical (Table 2), structural (Fig. 9) and physical tests on the kaolinitic material, pointed out a presumable

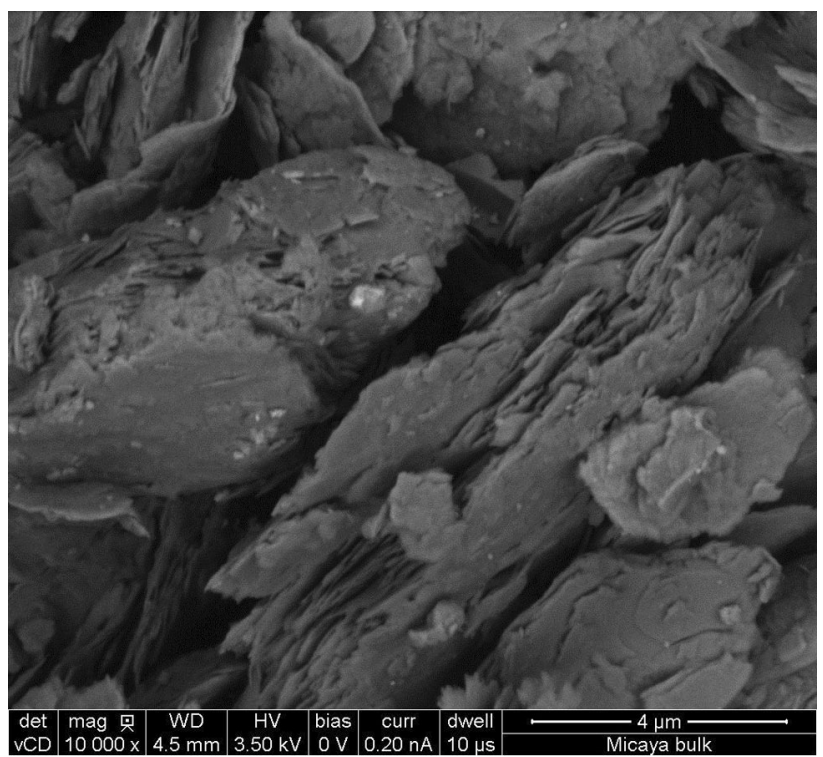

Fig. 9 SEM backscattered images from the kaolinitic sediments of Micaya 
use of these materials in the construction field as suitable raw materials for floor tile manufacture (Zeballos et al. 2016).

The raw material from Micaya is a whitish mixture that exhibits very fine grain size and is composed of quartz, kaolinite, muscovite and feldspar (Zeballos et al. 2016). Chemical analyses (Table 1) show 70.5 wt.\% $\mathrm{SiO}_{2}, 17$ wt. $\% \mathrm{Al}_{2} \mathrm{O}_{3}$ and 1.27 wt. $\% \mathrm{Fe}_{2} \mathrm{O}_{3}$, suitable composition for white ceramic formulations, due to the minimal iron content.

\section{Kaolinitic clay resources in Bolivia}

Kaolinitic occurrences in Bolivia are registered in several places, but they are poorly characterized and scarce data are available; in the current paper, some chemical and mineralogical analyses will be provided as general knowledge. In some deposits, the kaolinitic materials are associated with metallic ores like the deposit in the Santa Rosa mine located in La Paz, where mineralogical studies show the kaolin occurrence as a by-product of the hydrothermal alteration in the rocks which at the same time originated $\mathrm{Pb}, \mathrm{Au}$ and $\mathrm{Ag}$ anomalies. In Santa Cruz, several occurrences of kaolin were reported; those occurrences are mainly associated with pegmatitic rocks and tantalum/ beryllium mineralization such as in the Nuflo de Chavez Province, which are widely mined due to the tantalum content in the rock. In Oruro, the Itos deposit is a wellknown kaolin occurrence, and it is related to the $\mathrm{Sn}-\mathrm{Ag}$ mineralization in the Itos mine.

In the Santa Rosa mine, the argillization occurs associated with polymetallic veins where sandstones from the Tiwanaku Fm. were intruded by the Quimsachata dacitic porphyditic body (Orris et al. 1992; Rivas 2002). Several kaolinized areas were exploited by open-pit methods in the Quimsachata district following the metallic mineralization. Chemical analyses of the kaolinized alterations performed by Escobar et al. (1999) show 70.24 wt.\% $\mathrm{SiO}_{2}, 14.81$ wt. $\% \mathrm{Al}_{2} \mathrm{O}_{3}, 3.55$ wt. $\% \mathrm{~K}_{2} \mathrm{O}$ and 3.15 wt. $\% \mathrm{Fe}_{2} \mathrm{O}_{3}$, mapped as kaolinitic alteration; the silica-alumina relation shows poor kaolinization of the host rock. Available data of the raw materials point out the main application in the refractory ceramic industry, besides paints and absorbents. Escobar et al. (1999) have compared the Quimsachata kaolin deposit with the Itos deposit located in Oruro first studied by Chase (1948a). The Itos deposit was an important ore of metallic minerals such as $\mathrm{Ag}-\mathrm{Pb}-\mathrm{Sn}$ (Arduz et al. 1994). Chase (1948a) has described intense alteration in the Itos stock which is composed of $60 \%$ of feldspar, $20 \%$ of quartz and $20 \%$ of biotite. Although in his studies he mentions an intense alteration such as in the San Jose Breccia where the matrix is altered to sericite and kaolin and also a 20-cm-thick alunite and kaolinite veins at the Grande vein, mineralogical analyses are not available. Moricz et al. (2009) in their work about the mineralogy in the tails of the Itos mine report illite as the main clay phase in the mixture probably the sericitic material that Chase (1948b) mentioned before, which is present in an average of $20 \mathrm{wt} . \%$ in contrast to $2 \mathrm{wt} . \%$ of kaolinite of the total volume. The Itos deposit covers an extension of $300 \mathrm{~m}$ length, $30 \mathrm{~m}$ width and $6 \mathrm{~m}$ of thickness with a potential of 140,000 tonnes of material (Arduz et al. 1994).

The Altiplano and Cordillera Occidental several mines have been described with kaolinized sediments as a result of hydrothermal alteration along with metallic mineralization. Despite the geological data, chemical and mineralogical analyses are not available (See Geology and Mineral Resources of the Altiplano and Cordillera Occidental, Bolivia, 1992).

In Santa Cruz, economic occurrences of kaolinite are known and have been mined as ceramic raw materials for the local industry. Centellas (1990) has pointed out kaolinite occurrences associated with tantalum-columbite minerals in Santa Cruz as well as gold mineralization (Fernández 2012). Fernández (2012) in an important review about the mining industry in Bolivia has pointed out the mineralogy of the Concepcion district, which is composed of $\mathrm{Cu}-, \mathrm{Pb}-, \mathrm{Zn}-, \mathrm{Ag}-$ and Au-rich schist belts associated with quartz veins enriched in Au-, Sn-, W-, Nb-, Be-rich pegmatitic complexes besides kaolin as an alteration product; although the mineralogy was studied, no mineralogical or chemical results have been reported. The kaolin resources in Santa Cruz are the only kaolin resources proved to be of a good quality and are important resources (Fernández 2012), although the quality of the material and chemical and mineralogical results are not available.

For research purposes, in the present work several samples were analyzed from three deposits located in Santa Cruz; this will provide reliable data about kaolinite occurrences in the area: La Bella deposit is a kaolinite-rich pegmatitic complex intruded during the Sunsas orogeny (Litherland 1984; Arduz and Mobarec 1994) near to San Ramon town; the kaolinite in the deposit is a result of feldspar alteration, which is the main component in the pegmatites, and kaolin is the only mineral mined in the deposit; La Bella mine covers an extension $250 \mathrm{~m}$ long and $150 \mathrm{~m}$ wide, and the thickness varies from 1.50 to $33 \mathrm{~m}$ with a 112,000 tones reserve (Feraudy and Ruiz 1974); La Bella mine was formerly worked as an beryllium and muscovite ore (Rivas 2002). Located between San Ramon and Concepcion is the Misabo deposit in the Concepcion district, a well-known gold district in Santa Cruz, and it is associated with Au-rich kaolinized pegmatites where kaolinite and tantalum are by-products from the gold mining; $80 \mathrm{~km}$ from San Javier is located the Benton mine 
where tantalum/niobium-rich kaolinized pegmatitic rocks (Fig. 10) are mined for the tantalite mineral which is highly radioactive $(10 \mathrm{mR} / \mathrm{h})$.

Mineralogical analyses show kaolinite as the main component for the collected samples from the deposits; Misabo deposit exhibits $<20 \%$ quartz and feldspar content in the composition, in contrast to La Bella and Benton deposits which exhibit higher alumina content (Table 1). Morphological analyses (Fig. 11) on the feldspar-free samples exhibit a particular kaolinite habit, especially in La Bella, where needle-shape kaolinite crystals are highly widespread in the sample, as well as in the Benton 1 and Benton 2 samples where the acicular crystals (Fig. 12) are also present besides a clay matrix, in which kaolinite's platelets are easily identified.

\section{Common clay resources in La Paz}

\section{Common clay resources in Llojeta}

- Llojeta is located in La Paz city (Fig. 1), a well-known area in La Paz because vast clay resources from the La Paz Formation (Fig. 13) are exposed; several companies in the red brick commercialization are settled down in the area to minimize the transportation cost. The La Paz Formation consists in discontinuous beds of poorly consolidated sand, silt, gravel, clays (Dobrovolny 1955) and tuffaceous beds (Lavenu 1978; Thouveny and Servant 1989), tertiary in age (Posnansky 1920; Branisa 1954; Escobar et al. 1999) and fluvial in origin (Dobrovolny 1955).

These materials are in almost $70 \%$ of the La Paz red brick consumption and along with other factories in Cochabamba and Santa Cruz are in $90 \%$ of the national red brick consumption (Bustillos et al. 2004). The chemical analysis (Table 1) and the XRD results (Table 2) reveal

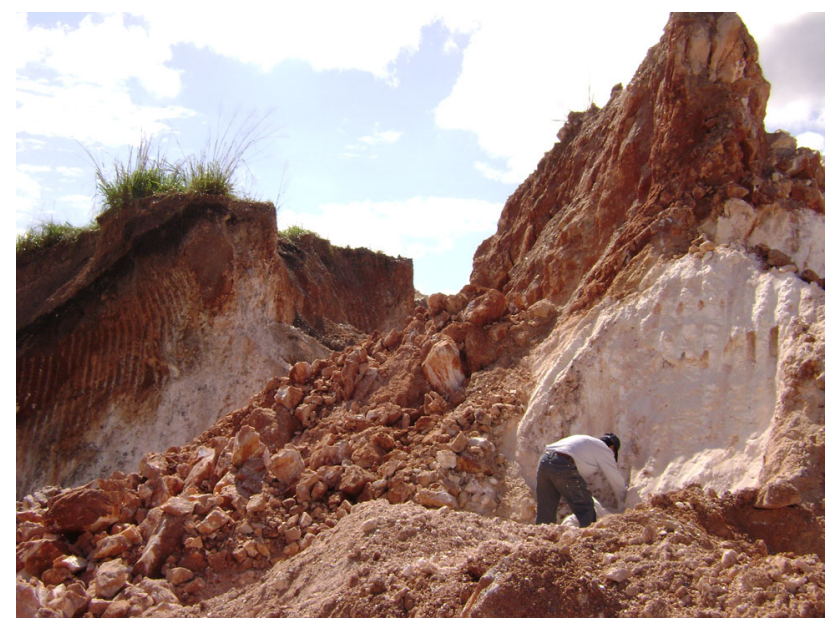

Fig. 10 Kaolin occurrences from Benton deposit, Santa Cruz

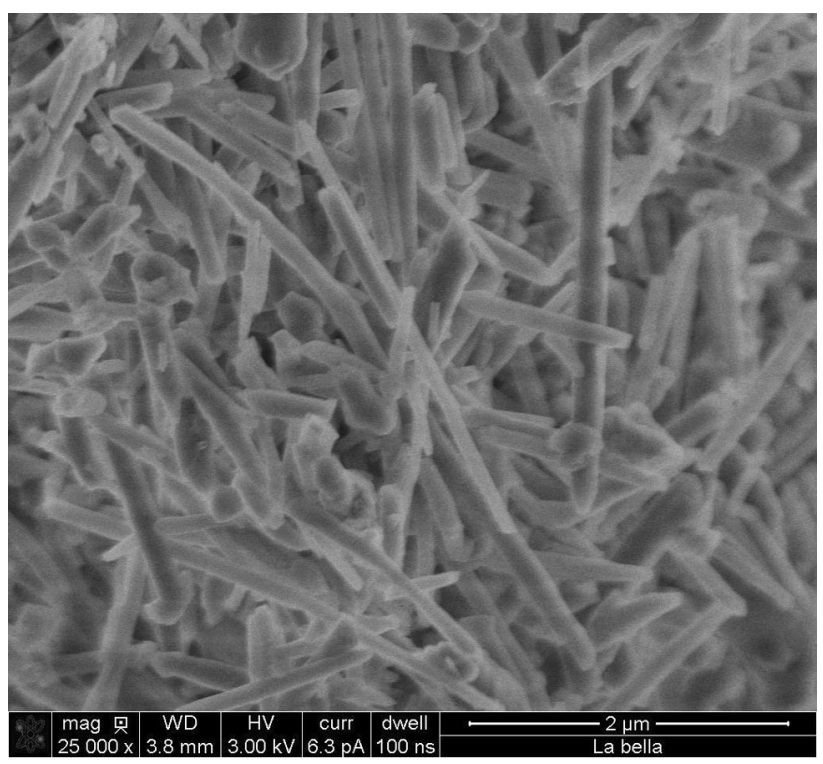

Fig. 11 Needle-shape kaolinite from La Bella deposit, Santa Cruz

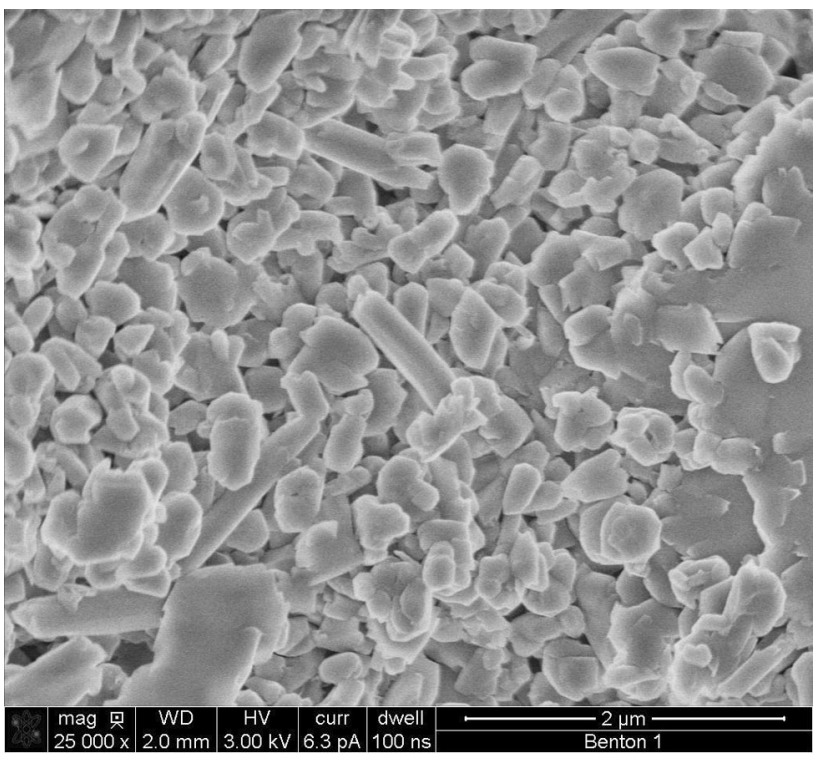

Fig. 12 Mixture of needle-shape kaolinite and platelets of kaolinite form Benton deposit, Santa Cruz

quartz as a major component along with muscovite and Illite as the principal clay constituent, a typical composition of a red brick raw material. A previous work (Escobar et al. 1999) in other areas, such as in Mallasa, Aranjuez, Cota Cota, pointed out La Paz Formation outcrops used, as well as in Llojeta, as raw materials for local red bricks producers.

\section{Common clay (ball clay) resources in Viacha}

- The Viacha municipality is located $18 \mathrm{~km}$ from "El Alto" city (Fig. 1), where ceramic factories are located 


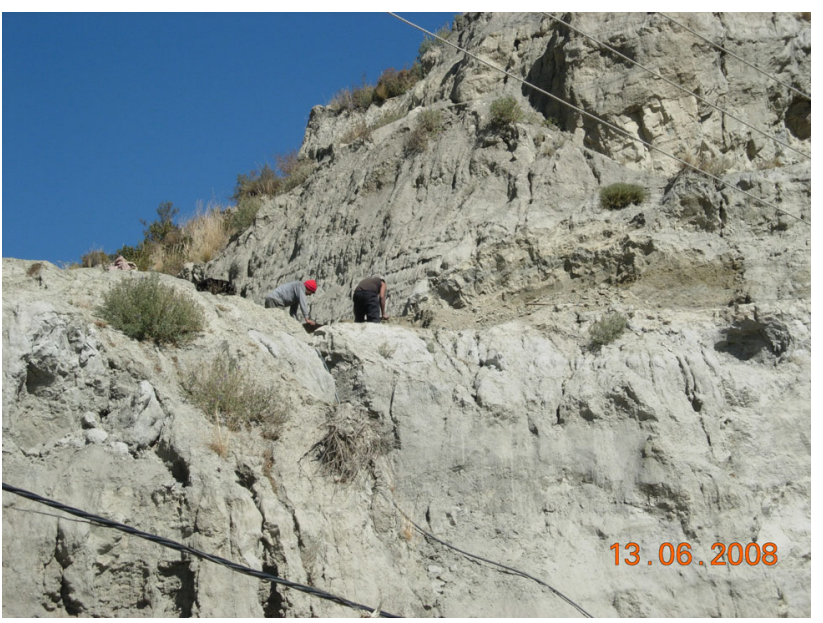

Fig. 13 Illitic clays deposit from Llojeta, La Paz

around the town. The clay deposit owned by INCER$\mathrm{PAZ}$, one of the major ceramic producers in Bolivia, is located $4 \mathrm{~km}$ from Viacha, The INCERPAZ's deposit consists of brownish clays intercalated with siltstones and fine-grained sand from the Ulloma Formation which is lacustrine in origin. Tables 1 and 2 show the chemical and mineralogical analyses performed in the collected samples.

\section{Ball clays resources in Bolivia}

Ball clay resources are widespread in Bolivia, although most of the deposits are not well described or studied; the red brick industry has worked on most of them, and some of those deposits will be described below.

\section{Paleozoic sediments}

The Belén Formation, Devonic in age, is composed of siltstones, mudstones and fine-grained sandstones, marine in origin; the finest lithology has been exploited for ceramic purposes in three areas close to Batallas town: Chillu, Karhuisa and Warmimarka (Escobar et al. 1999). The Chillu deposit located at $1.5 \mathrm{~km}$ from Batallas belongs to the lower sediments of the Belen Fm. which consist mainly of mudstones, and it is approximately $200 \mathrm{~m}$ long and $20 \mathrm{~m}$ thick. The raw material is composed of $60.25 \mathrm{wt} . \%$ $\mathrm{SiO}_{2}, 21.69$ wt.\% $\mathrm{Al}_{2} \mathrm{O}_{3}$ and 6.30 wt. $\% \mathrm{Fe}_{2} \mathrm{O}_{3}$ (Escobar et al. 1999), used in pottery.

The Karhuisa deposit is located $7 \mathrm{~km}$ from Batallas; it consists of altered mudstones, yellowish in color between the siltstones and sandstones in the Belen Fm. The Karhuisa deposit is composed of 55.52 wt. $\% \mathrm{SiO}_{2}, 19.93$ wt.\% $\mathrm{Al}_{2} \mathrm{O}_{3}$ and 6.83 wt. $\% \mathrm{Fe}_{2} \mathrm{O}_{3}$ (Escobar et al. 1999); the raw material has been used since 1992 in the red brick manufacturing. The Warmimarka deposit exhibits the same lithological characteristics as the Karhuisa deposit; the chemical composition 63.94 wt. $\% \mathrm{SiO}_{2}, 18.48$ wt. $\% \mathrm{Al}_{2} \mathrm{O}_{3}$ and 3.99 wt. $\% \mathrm{Fe}_{2} \mathrm{O}_{3}$ (Escobar et al. 1999) reveals the possible application of the material in the ceramic industry.

In the central Altiplano, tertiary clay sediments have been described in several locations: at the Kollu Kollu Fm in Laja and Chua municipalities, at the $\mathrm{La} \mathrm{Paz} \mathrm{Fm} \mathrm{in} \mathrm{La}$ Paz city and the Ulloma Fm in Jesús the Machaca municipality; additionally, some deposits have been registered and studied in Potosí and Cochabamba.

\section{Paleogene sediments}

The Catavi deposit located $52 \mathrm{~km}$ from La Paz over the Kollu Kollu Fm is composed of red shales and sandstones besides those evaporitic layers such as gypsum and limestone that have been identified. The Catavi deposit is chemically composed of 52.50 wt. $\% \mathrm{SiO}_{2}, 23.43$ wt.\% $\mathrm{Al}_{2} \mathrm{O}_{3}, 1.23$ wt. $\% \mathrm{CaO}$ and 6.73 wt. $\% \mathrm{Fe}_{2} \mathrm{O}_{3}$, although not commercially developed; some local workers have used the raw material for brick manufacture (Escobar et al. 1999). Another deposit from the Kollu Kollu Formation is the Chua Grande deposit located $22 \mathrm{~km}$ from Huarina; in this section, the sedimentary unit is composed of sands, tuffs and clays, yellowish in color and has an extension of $10,000 \mathrm{~m}^{2}$ mined by hand methods with an alumina content of 20.4 wt.\% $\mathrm{Al}_{2} \mathrm{O}_{3}$ (Escobar et al. 1999).

\section{Neogene sediments}

In Potosí, the Sacaca deposit is located $7 \mathrm{~km}$ away of Sacaca town in the Jachuma Hill; the deposit is located in a sedimentary basin within small hills, consisting of small clay occurrences; the origin of the sediments is unknown; nevertheless, a lacustrine evaporation process is suggested due the gypsum content in the sediments; the sedimentary units are undetermined, although Claure et al. (1996) assign the Bolivar Fm as the sedimentary unit. The Sacaca deposit consists of a basal conglomerate overlain by a white silty-sandy bed, a horizon of a coarse-grained sand, a light color clay bed with $20 \%$ of gypsum, $28 \mathrm{~m}$ thick and 600 long and of $1.6 \mathrm{~m}^{3}$, and composed of illite and kaolinite (Claure et al.1996).

In La Paz city, the well-developed La Paz Formation is composed mainly of clays and gravel fluvio-glacial in origin. The clay has been used for many years as a raw material for the red brick industry as the main source of ceramic-building materials besides Cochabamba to import in Bolivia.

The La Paz Fm. crop out in several places; in the La Paz basin, the most exploited deposits are those located in Llojeta described before in this study; other deposits are located in Mallasilla where the production is over 7000 units/d, from a deposit $100 \mathrm{~m}$ long and $15 \mathrm{~m}$ high (Escobar et al. 1999); In the Achumani zone, the BRIKO factory reports that the used raw material belongs to siltstones layers from la Paz Fm, is gray in color and used mainly in roofing ceramics. Those deposits located in the Kantutani 
zone are small in size and are used in the local commercialization with 1700 units/d (Escobar et al. 1999); along with these deposits, several others were sketched from the sediments of the La Paz Fm. located in Ovejuyo, Cota Cota, Aranjuez and Achachicala; no production data are available.

\section{Quaternary sediments}

The Ulloma Formation hosts vast clay resources used in the manufacture of red bricks as well as those raw materials from the La Paz Fm. The Tocari and Jilakhata deposits are located near Jesús de Machaca and are constituted by clays, siltstones and gravel of fluvio-lacustrine origin; the clays of the Tocari deposit are composed of 57.33 wt. $\% \mathrm{SiO}_{2}, 14.16$ wt. $\% \mathrm{Al}_{2} \mathrm{O}_{3}, 9.95$ wt.\% $\mathrm{CaO}$ and 5.29 wt. $\% \mathrm{Fe}_{2} \mathrm{O}_{3}$; the sediments are distributed in 3-4-m-thick layers in the Ulloma Fm (Escobar et al. 1999). The khellani deposit materials are currently used in the manufacture of bricks with a production rate of 6000 units/day constituted of clays and siltstones with calcareous crusts; the mineralogical analysis shows quartz and illite as major components.

The Altiplano is an infill basin of lacustrine sediments, sediments that came from the oldest Minchín lake and the old Ballivian lake; as lacustrine sediments, the predominant mineralogy are illitic-rich clays, widely used in the manufacture of bricks and roofing tiles. The local ceramic manufacture represents an important economical movement in some municipalities such as San Andrés de Machaca, Viacha, Tiahuanacu, Batallas and Achacachi in the La Paz department (Escobar et al. 1999) and between Challacollo and Toledo in Oruro where the deposit consist of 2-m-thick reddish horizon; Claure et al. (1996) pointed out illite as the major component in the clay sediment, along with kaolinite and montmorillonite as the minor components.

Asher-Bolider et al. (1992) describe the CORDEOR clay pit, located in Oruro, in lacustrine deposits to be quaternary in origin and illitic in composition; 2,000,000 tons have been approximately calculated by Montes de Oca (1982) as raw material to be used in local red brick factories.

\section{Mullite}

The mullite is a rare mineral discovered in Mull (Scotland), seldom found in nature, but produced artificially by heating silica and alumina. C-E Minerals dominate a synthetic mullite production by mixing and heating various grades of bauxitic clays (Sweet et al. 2006). Synthetic mullite are generally produced by four processes: (1) melting alumina and silica or bauxite and kaolin at $1914{ }^{\circ} \mathrm{C}$; (2) sintering alumina-rich minerals such as kaolin, bauxita or kyanite at $1763{ }^{\circ} \mathrm{C}$; (3) calcining kyanite at $1300{ }^{\circ} \mathrm{C}$ or (4) sintering siliceous bauxite or mixtures of bauxite and kaolin at $1561{ }^{\circ} \mathrm{C}$.

The mullite mineral imparts to the products in which it is used high refractoriness and low coefficient of thermal expansion; it confers them great resistance to thermal shock and resistance to the chemical corrosion. In Bolivia, no occurrences of this mineral have been detected.

Comeforo et al. (1948) working in mullitization from kaolinites studied the thermal behavior of kaolinites from Georgia in this experiment; it is shown mullite crystallized from kaolinites, the firing process develops two stages of crystallization, between 500 and $600{ }^{\circ} \mathrm{C}$ the hydroxyl groups are expelled from the structure and at $1000{ }^{\circ} \mathrm{C}$, a crystallization of a new phase starts called "metakaolin" or "pro-mullite."

From the kaolinitic residual deposit located in Micaya, La Paz (Fig. 1), Zeballos et al. (2013) have proposed a second application, a synthetization of mullite. The raw material used in the mullite synthetization was discussed above; a geological background and chemical analyses were presented in the building materials section.

Based on chemical analyses (Table 1) and XRD mineral peak position (Table 2), Zeballos et al. (2013) performed a mullite synthetization using kaolinite-bearing sediments as raw material from Micaya. The performed process is a ramp/hold firing program, where the heating rate process is timely controlled as well as the cooling process leaving a slow crystallization process. Three heating and holding stages were defined: (1) $0{ }^{\circ} \mathrm{C}-570{ }^{\circ} \mathrm{C} / 30 \mathrm{~min}$, (2) $570{ }^{\circ} \mathrm{C}-$ $1100{ }^{\circ} \mathrm{C} / 30$ min and $(3) 1100{ }^{\circ} \mathrm{C}-1250{ }^{\circ} \mathrm{C} / 30 \mathrm{~min}$, and the resulting material was a mixture where acicular mullite crystals are visible (Fig. 14).

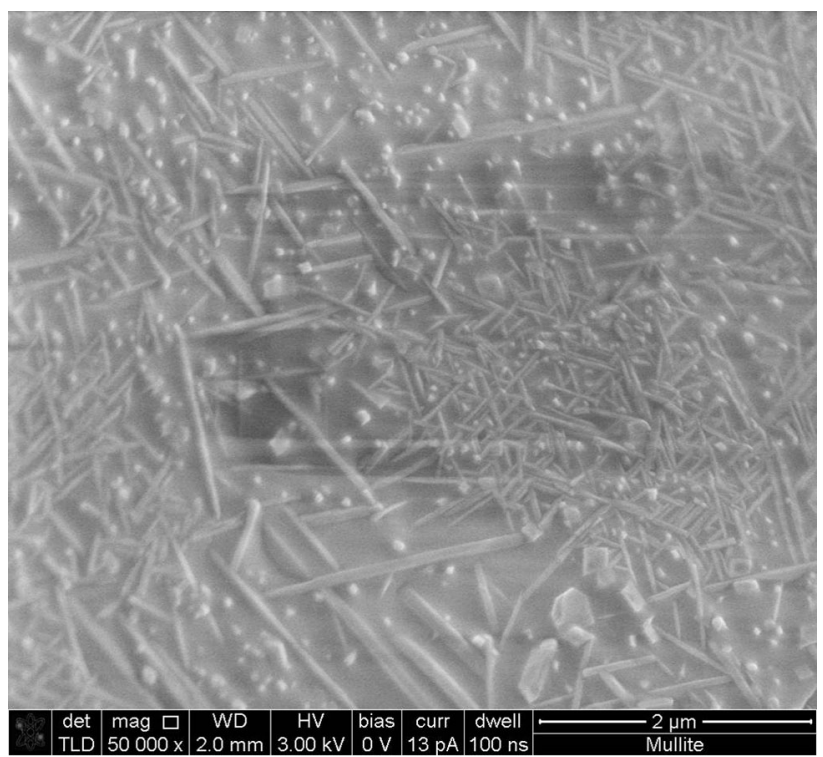

Fig. 14 Acicular mullite crystals, synthetized from kaolinitic sediments 


\section{Refractory minerals in Bolivia}

Sanz et al. (2003) reported refractory minerals widely widespread in Oruro, in areas such as San Pedro, Corque, Pampa Aullagas, Andamarca, Isla de Panza and Salinas de Garcí Mendoza; no specifications in the mineral composition in these studied areas were reported.

Close to La Paz city in the Zongo Valley, 15-cm-long crystals of andalucite were discovered in the metamorfized Coroico Fm. with a 10 wt.\% concentration (Rivas 2002). Ávila-Salinas (1989) determined quiastolite from the andalucite family as the main mineral, whitish in color due to the $2 \%$ concentration of $\mathrm{Fe}_{2} \mathrm{O}_{3}$ and of 5.8 million tons.

\section{Nonmetallic market in Bolivia (import-export)}

Bolivia is an important player in mineral exportations and has been one of the export leaders in tin, lead, zinc among others. In (1970), Arthur D. Little Inc. made a first survey about the opportunities of the nonmetallic minerals industry in Bolivia, and the conclusions indicate construction materials, glass, ceramic tile, magnesite, asbestos and vitreous plumbing as good opportunities of resources, market and technology.

The mining industry was for several years the main income of Bolivia, and now it became important again thanks to the Mutún at the eastern part of Bolivia and the Uyuni salt lake at the western side of the country. Bolivia has been characterized as a mining country since the days of the colony; beginning of 1545 is the year that is given to the cycle of mining, in which mineral exploitation begins, mainly silver. Around 1900, the ore mineral deposits were worked by private owners as the likes of Patiño, Aramayo and Hochschild. In 1952 comes the nationalization of mines and COMIBOL (Bolivian Mining Corporation) is founded. COMIBOL is the company responsible for the old mine workings as well as the current ones.

The Uyuni Salar flat is the main nonmetallic mining prospect in Bolivia and has a surface of $10,582 \mathrm{~km}^{2}$, home for $70 \%$ of the lithium reserve with a 100 million tons of reserve (Office of Evaporitic Resources 2010). The nonmetallic mineral deposits in general are slightly known and less exploited due the low trade value; nevertheless, some nonmetallic minerals acquire relative importance as raw materials, such as limestones, dolomite and clays.

In 2010 , the median mining contributed with $36.73 \%$, the small mining and cooperative mining with $55.80 \%$ and the state-owned mining with $7.45 \%$ (Ministry of Mining and Metallurgy 2010). The nonmetallic minerals are represented in the small mining, in minerals such as ulexite $\left(97,302.03 \mathrm{~m}^{3}\right), \quad$ barite $\quad\left(7844.67 \mathrm{~m}^{3}\right)$, amethyst $\left(485,390 \mathrm{~m}^{3}\right)$, bentonite $\left(440,000 \mathrm{~m}^{3}\right)$ casing stones $\left(728,604 \mathrm{~m}^{3}\right), \quad$ tantalite $\left(3416 \mathrm{~m}^{3}\right)$ and limestone $\left(111,450 \mathrm{~m}^{3}\right)$. During 2010 , the export value reached a value of USD 3,410,254 with an export volume of 3,156,069 fine metric tons (Ministry of Mining and Metallurgy 2010). During 2010, Bolivia has exported $42 \%$ to Asia, $28 \%$ to Europe, $28 \%$ to America and $2 \%$ to Oceania and Africa (Ministry of Mining and Metallurgy 2010).

The cement Industry in Bolivia

Cement is one of the main industrial products made of nonmetallic minerals, which uses limestone, clay and gypsum which is added to control the setting. Bolivia produces portland cement and pozzolanic cement that mix clinker with $30 \%$ of pozzolana increasing the resistance of the salt water attack and fracturing. The clinker occurs as lumps or nodules, usually 3 to 25 millimeters in diameter, produced by sintering limestone and aluminosilicate materials such as clay during the cement kiln stage.

The pozzolans are materials bound to volcanism or materials that exhibit pozzolaneity. The pozzolaneity is a reaction developed between the silica of the raw material itself and the calcium hydroxide of the cement in the presence of water; among the materials used are tuffs and ignimbrites. Deposits of tuffs are located near the city of Sucre, in the Huayllas and Calera occurrences, whose materials are whitish to greenish gray with varying contents of biotite and silty clay sediments (Arduz et al. 1992). In La Paz area, $25 \mathrm{~km}$ southwest to La Paz, the Ventilla deposit is composed by rhyodacitic tuff horizons intercalated with sand and clays from the Umala Fm. The important horizon is $2.0-3.0 \mathrm{~m}$ thick and $100 \mathrm{~m}$ long; close to Villa Remedios, the same horizon from the Umala Fm is $4.8 \mathrm{~m}$ thick (Arduz and Buitrago 1992).

The cement industry in Bolivia is represented by six companies, SOBOCE (La Paz), FANCESA (Sucre), COBOCE (Cochabamba), ITACAMBA (Santa Cruz), YURA (Perú), ITAÚ (Brasil). In 2015, the cement industry has grown in over $8.4 \%$, leading the sales SOBOCE accounting for a 1,537,012 tons in 2015 (SOBOCE 2015), FANCESA with a 989,563 tons, COBOCE with a 677,821 tons, ITACAMBA with a 168,270 tons and Yura with a 296,972 (Press report, 2016). Four plants will be installed in the future: the state company ECEBOL (Oruro) will initiate operation in 2019 with 3000 tpd, Itacamba (Santa Cruz) will operate 2000 tpd in 2017, FANCESA (Sucre) will operate 2000 in 2019 (Press report, 2016) and SOBOCE will initiate operation in a new plan in Santa Cruz de la Sierra accounting for 1000 tpd in 2020 (SOBOCE 2015).

Acknowledgements This study was funded by the Swedish Development Agency (SIDA). We express our enormous gratitude to the Institute of Geology and Environment (IGEMA). 
Open Access This article is distributed under the terms of the Creative Commons Attribution 4.0 International License (http://crea tivecommons.org/licenses/by/4.0/), which permits unrestricted use, distribution, and reproduction in any medium, provided you give appropriate credit to the original author(s) and the source, provide a link to the Creative Commons license, and indicate if changes were made.

\section{References}

Acarapi W (2013) Estudio y aplicación de los recursos diatomaceos de las localidades de Charaña y Bella Vista, departamentos de La Paz y Potosí. Dissertation, Universidad Mayor de San Andrés, La Paz, Bolivia

Almendras AO, Menacho LM, Miranda AV (2002) Depósitos metálicos y áreas prospectivas de la región de Río Mulatos. Final Proc. Bolivian Conf. of Geology. Santa Cruz, Bolivia, pp 12-17

Arduz M, Buitrago O (1992) Minerales y rocas industriales en Bolivia: Una alternativa de diversificación. Bol Soc Geol Boliv La Paz 27:12-13

Arduz TM, Mobarec CR (1994) Final Proc. Bolivian Conf. of Geology. Santa Cruz, Bolivia, pp 340-342

Arduz M, Burgos G, Quiroga J (1991) Programa de Investigación de minerales industriales en el Departamento de Tarija - Bolivia. Informe inédito, GEOBOL

Arduz M, Troncoso D, Asebey J, Camacho A (1992) Proyecto de exploración y evaluación de minerales industriales en el Departamento de Chuquisaca - Bolivia. Informe inédito, GEOBOL

Arduz TM, Almeida L, Claure H (1994) Final Proc. $7^{\circ}$ Chilean Conf. of Geology: Volume II. Concepción, Chile, pp 720-724

Asher-Bolinder S, Soria EE, Orris JG (1992) CORDEOR clay pit. In: Cox PD, Carrasco R, Andre RO, Hinojosa VA, Long RL (eds), Cooper deposits in sedimentary rocks United States Government Press Office, pp 206-207

Arthur D Little Inc., Prudencio Claros y Asociados (1970) Estudio de Oportunidades para la industria Boliviana. Industria de Metales No-Ferrosos, Ministerio de Gobierno, vol 2, p 29

Ávila-Salinas W (1989) Perspectivas sobre la explotación y aplicación industrial de la andalucita de Yani - Zongo. CEDOMIN No 11

Ballivian O, Risacher F (1981) Los salares del Altiplano boliviano; métodos de estudio y estimación económica: Paris and La Paz. L 'Office de Ia Recherche Scientifique et Technique Outre - Mer and Universidad Mayor de San Andres

Blanco M, Conde J, Cabrera S (2003) Síntesis de wollastonita a partir de precursores naturales (toba y diatomite). Final Proc. Bolivian Conf. of Geology, Oruro, Bolivia, pp 357-361

Branisa L (1954) Geología del Valle de La Paz. El Diario and La Nación newspaper reporting, La Paz, Bolivia

Brown G, Brindley GW (1980) X-ray diffraction procedures for clay mineral identification. In: Brindley GW, Brown G (eds) Crystal structures of clay minerals and their X-ray identification. Miner Soc Monogr 5:305-359

Bustillos R, Carrasco C, Duran L (2004) Determinación de los Impactos Ambientales de la viruta de cromo empleada para la fabricación de ladrillos. Final report, National Chamber of Industry -IIDEPROQ

Carty MW, Senapati U (1998) Porcelain-raw materials, processing, phase evolution, and mechanical behaviour. J Am Ceram Soc 81(1):3-20

Centellas CR (1990). Algunas manifestaciones de minerals de rendimiento económico. In: Yacimientos Petrolíferos Fiscales
Bolivianos Technical journal, Final Proc. IX Bolivian Geological Conference, vol. 11(2-3), pp 317-321

Chang LY (2002) Industrial mineralogy: materials, processes and uses, 1st edn. Prentice Hall, Upper Saddle River

Chase MF (1948a) Tin-Silver veins of Oruro, Bolivia (I Part). Bull Econ Geol 43(5):333-383

Chase MF (1948b) Tin-Silver veins of Oruro, Bolivia (II Part). Bull Econ Geol 43(6):435-470

Claure VH, de Oliveira AL, Arduz TM (1996) Deposits of industrial minerals and rocks. In: Troëng B, Riera KC (eds) Thematic maps of mineral resources of Bolivia, Uncía geological sheet. Bulletin Geological Survey of Bolivia, vol 7, pp 43-62

Comeforo E, Fischer R, Bradley W (1948) Mullitization of Kaolinite. J Am Ceram Soc 31(9):254-259

Cortez R, Lima CE (2002) Resultados de prospección geoquímica en el area Llica - Bella Vista. Final Proc. Bolivian Conf. of Geology. Santa Cruz, Bolivia, pp 275-278

Cox PD, Carrasco R, Andre RO, Hinojosa VA, Long RL (1992) Cooper deposits in sedimentary rocks. In: U. S. Geological Survey editors, United States Government Press office, pp. 95-209

Dobrovolny E (1955) Preliminary report of the geology of the Upper Las Paz valley, Bolivia. U.S. Geological Survey, Report

Encinas E, Zubieta E, Rojas J (2007) Remoción de Cadmio proveniente de la actividad minera mediante materiales arcillosos. In: J. Feyen, L. Aguirre, M. Moraes (Editors), International Congress on Development, Environment and Natural Resources: Multi-level and Multi-scale Sustainability, Cochabamba - Bolivia, pp 873-880

Entwistle PL, Gouin OL (1955) The chalcocite-ore deposits at Coro coro, Bolivia. Bull Econ Geol 50(6):555-570

Escobar DA, Bellot J, Jurado AE (1999) Minerales y rocas industriales. In: Riera KC, Troëng B, Diaz ME, Jurado AE (eds) Integrated studies of the mineral resources of Bolivia. La Paz and Copacabana Geological sheet. Geological Survey of Bolivia, Bulletin, vol 22, pp 75-117

Everden F, Kriz S, Cherroni C (1966) Correlaciones de las formaciones terciarias de la cuenca altiplánica a base de edades absolutas determinadas por método potasio - argon. Report (1). Geological Survey of Bolivia

Eyde HT, Holmes AD (2006) Zeolites. In: Kogel J, Trivedi N, Barker J, Krukowski S (eds) Industrial minerals \& rocks, 7th edn, Society for Mining, and Exploration Inc., pp 1039-1064

Feraudy C, Ruiz G (1974) Kaolin project: Evaluation and reserves calculation of kaolin deposits. Geological Survey of Bolivia, Bulletin GE-61

Fernández TJ (2012) La minería y la problemática medioambiental en Bolivia. In: Fernandes A, Furtado L (eds) Minería y actuación del ministerio público en Latinoamérica. Latin American network of Environmental Public Prosecutor, Brazil, pp 67-93

Frenguelli J (1939) Diatomeas del Lago Titicaca. Notes Mus, La Plata, vol 4, pp 175-196

Garcia G, Aguilar-Mamani W, Cabrera S, Hedlund J, Mouzon J (2015) Preparation of zeolite A with excellent optical properties from clay. J Alloys Compd 619:771-777

Guerra M, Ascarrunz KR (1964a) Informe sobre el estudio de yacimiento bentonítico mina La Encontrada: Bolivia. Report (DNG-M-342), Geological Survey of Bolivia

Guerra M, Ascarrunz KR (1964b) Informe sobre orientación técnica mina cuprífera La Encontrada: Bolivia. Report (DNG-M-343), Geological Survey of Bolivia

I. N. E. (2013) Estadísticas de la actividad de la Construcción. Statistical National Institute from Bolivia. Statistical report. La Paz, pp 33-36 
Lavenu A (1978) Néotectonique des sédiments Plio-Quaternaire du nord de L'Altiplano Bolivien (région de La Paz-Ayo AyoUmala). Cah ORSTOM Sér Géol X(1):115-126

Lavenu A (1991) Formación Geológica y Evolución. In: Dejoux C, Iltis A (eds) El Lago Titicaca - Síntesis del Conocimiento limnológico actual. ORSTOM, Hisbol Press, La Paz, pp 19-27

Litherland M (1984) Precambrian Geological Sheet. GEOBOL-BGS, esc. 1:1000000. Cook, Hammond \& Kell, Inglaterra

Ludington S, Orris GJ, Cox DP, Long KR, Asher-Bolinder S (1992) Mineral deposit models. In: U. S. Geological Survey editors, United States Government Press office, pp 63-89

Ministry of Mining and Metallurgy of Bolivia (2010) Data Base of the Ministry

Mobarec CR, Murillo SF, Arduz TM (1996) Deposits of industrial minerals and rocks. In: Troëng B, Riera KC (eds) Thematic maps of mineral resources of Bolivia, Corque and Payachata snow Hills geological

Moharem AF, Saleh AE (2007) Properties and suitability of Wadi Zarieb Feldspars for ceramic industries in Egypt. J Appl Sci 7(19):2794-2799

Montes de Oca I (1982) Geografía y recursos naturales de Bolivia. Superel Ltd Press, La Paz

Moore D, Reynolds R (1997) X-ray diffraction and the identification and analysis of clay minerals. Oxford University Press, Oxford, p 371

Moricz F, Walder FI, Madai F (2009) Geochemical and mineralogical characterization of waste material from the Itos $\mathrm{Sn}-\mathrm{Ag}$ deposit, Bolivia. Final Proc. Int. Conf. Securing the Future and 8th ICARD, Skellefteå, Sweden

Office of Evaporitic Resources of Bolivia (2010) Informative report and memories 2010. La Paz - Bolivia

Orris JG, Asher-Bolider S, Soria EE, Enriquez RR, Bailey AE (1992) Laguna Colorada. In: Cox PD, Carrasco R, Andre RO, Hinojosa VA, Long RL (eds) Cooper deposits in sedimentary rocks. United States Government Press Office, pp 201-202

Panoso Y (2015). Estudio Geológico y Caracterización del Depósito Bentonítico y sus aplicaciones Potenciales, en la Localidad Putuni - Condoroca, Provincia Pacajes, Departamento de La Paz. Dissertation, Universidad Mayor de San Andrés, La Paz, Bolivia

Parker MP (2008) The 2009-2014 World outlook for Non-metallic mineral mining and quarrying. ICON Group International, Inc Press, San Diego, p 191

Posnansky A (1920) Bolivia. Soc. Geogr (28:51-52), La Paz

Rivas S (2002) Minerales No-Metálicos, Rocas Industriales y Gemas de Bolivia. Landivar Press, Bolivia, p 355

Sanfeliu T, Jordán MM (2009) Geological and environmental management of ceramic clay quarries: a review. Environ Geol 57:1613-1618
Sanz MF, Gutierres ZF, Echeverria MP (2003) Potencial económicosocial del Departamento de Oruro, Bolivia. Cartagena agreement team -Andean Cooperation Program to Bolivia, Oruro

Servant M, Fontes JC (1978) Les lacs quaternaires des hauts plateaux des Andes boliviennes. Premieres interprétations paléoclimatiques. Cah ORSTOM Sér Géol 10(1):9-23

Servant-Vildary S (1978a) Les diatomées des dépôts lacustres quaternaires de I' Altiplano bolivien. Cah ORSTOM Sér Géol $\mathrm{X}(\mathrm{I}): 25-35$

Servant-Vildary S (1978b) Les diatomées des dépôts lacustres quaternaires de I' Altiplano bolivien. Cah ORSTOM sér Géol $\mathrm{X}(\mathrm{I}): 55-102$

Shenk JD (1991) Lacustrine diatomite. In: Orris GJ, Bliss JD (eds) Some industrial mineral deposit models-descriptive deposit models: U.S. Geological Survey Open-File, Report 91-11A, pp 23-25

Sociedad Boliviana de Cemento (2015) Escenario Competitivo de la industria. Informe Interno

Soria FA (1980) Estudio hidrogeológico del área Viacha, Surusaya y Villa Remedios. Thesis, Universidad Mayor de San Andrés, La Paz, Bolivia

Sweet P, Dixon G, Snoddy J (2006) Industrial Minerals \& Rocks. In: Kogel J, Trivedi N, Barker J, Krukowski S (eds) Kyanite, Andalusite, Sillimanite and Mullite: Society for Mining, and Exploration Inc., pp 553-560

Thouveny N, Servant M (1989) Palaeomagnetic stratigraphy of Pliocene continental deposits of the Bolivian Altiplano. Palaeogeogr Palaeoclimatol Palaeoecol 70:331-344

Troëng B, Claure H et al (1993) Thematic maps of the Mineral Resources of Bolivia, Tarija and Villazon Sheets

U.S. Geological Survey and Bolivian Geological Survey (1992) Geology and Mineral Resources of the Altiplano and Cordillera Occidental, Bolivia. In: U.S. Trade and development program. United States Government Press office

Zeballos A, Blanco M, Machaca V (2009) Caracterización Mineralógica y Fisicoquímica de una Lutita Blanca de la Localidad de Micaya, La Paz. Memorias Congr. Nal. Geología XIV, Potosí-Bolivia, 2009. Ed. Comisión Científica Nacional, pp 230-233

Zeballos A, Weihed P, Blanco M, Machaca V (2013) Mullite synthetization at low temperature. Final Proceedings of the International Conference Mineral deposit research for a hightech world, Uppsala, Sweden, pp 1784-1786

Zeballos A, Weihed P, Blanco M, Machaca V (2016) Geological, mineralogical and chemical characterization of Devonian kaolinite-bearing sediments for further applications in the ceramic (tile) industry in La Paz, Bolivia. Environ Earth Sci 75(5):1-15 